\title{
Systematic Review of Clinical Applications of CAD/CAM Technology for Craniofacial Implants Placement and Manufacturing of Orbital Prostheses
}

\author{
Waqas Tanveer ${ }^{1, *}$, Angela Ridwan-Pramana ${ }^{2}$, Pedro Molinero-Mourelle ${ }^{3}\left[\right.$ and Tymour Forouzanfar ${ }^{4}$ \\ 1 Department of Oral and Maxillofacial Surgery, Amsterdam University Medical Center, \\ 1081 HV Amsterdam, The Netherlands \\ 2 Center for Special Care in Dentistry, Department of Maxillofacial Prosthodontics, \\ Stichting Bijzondere Tandheelkunde, 1081 LA Amsterdam, The Netherlands; a.ridwan@amsterdamumc.nl \\ 3 Department of Reconstructive Dentistry and Gerodontology, School of Dental Medicine, University of Bern, \\ CHE 3012 Bern, Switzerland; pedro.molineromourelle@zmk.unibe.ch \\ 4 Department of Oral and Maxillofacial Surgery/Oral Pathology and 3D Innovation Lab, \\ Amsterdam University Medical Center, 1081 HV Amsterdam, The Netherlands; t.forouzanfar@amsterdamumc.nl \\ * Correspondence: w.tanveer@amsterdamumc.nl; Tel.: +31-644-200-096
}

Citation: Tanveer, W.;

Ridwan-Pramana, A.;

Molinero-Mourelle, P.; Forouzanfar, T

Systematic Review of Clinical

Applications of CAD/CAM

Technology for Craniofacial Implants

Placement and Manufacturing of

Orbital Prostheses. Int. J. Environ. Res.

Public Health 2021, 18, 11349. https://

doi.org/10.3390/ijerph182111349

Academic Editors: Stefano Di Carlo,

Luigi Vito Stefanelli,

Grecchi Francesco, Gerardo Pellegrino and Alessio Franchina

Received: 28 September 2021

Accepted: 22 October 2021

Published: 28 October 2021

Publisher's Note: MDPI stays neutral with regard to jurisdictional claims in published maps and institutional affiliations.

Copyright: (c) 2021 by the authors. Licensee MDPI, Basel, Switzerland. This article is an open access article distributed under the terms and conditions of the Creative Commons Attribution (CC BY) license (https:// creativecommons.org/licenses/by/ $4.0 /)$
Abstract: This systematic review was aimed at gathering technical and clinical applications of $\mathrm{CAD} / \mathrm{CAM}$ technology for the preoperative planning of craniofacial implants placement, designing of molds and substructures and fabrication of orbital prostheses. Following the Preferred Reporting Items for Systematic Reviews and Meta-Analysis (PRISMA) guidelines, an electronic search was executed. Human studies that utilized digital planning systems for the prosthetic rehabilitation of orbital defects were included. A total of 16 studies of 30 clinical cases, which were virtually planned through various digital planning and designing software, were included. The most common preoperative data required for digital planning were CT scans in 15 cases, the 3DSS-STD-II scanning system in 5 cases, an Artec Color 3D scanner in 3 cases and a NextEngine Desktop 3D laser scanner in 2 cases. Meanwhile, the digital designing software were Ease Orbital Implant Planning EOIPlan software in eight cases, Geomagic software in eight cases, Simplant software in four cases and Artec Studio 12 Professional in three cases. Surgical templates were fabricated for 12 cases to place 41 craniofacial implants in the orbital defect area. An image-guided surgical navigation system was utilized for the placement of five orbital implants in two cases. Digital designing and printing systems were reported for the preoperative planning of craniofacial implants placement, designing of molds and substructures and fabrication of orbital prostheses. The studies concluded that the digital planning, designing and fabrication of orbital prostheses reduce the clinical and laboratory times, reduces patient visits and provide a satisfactory outcome; however, technical skills and equipment costs are posing limitations on the use of these digital systems.

Keywords: orbital prosthesis; digital planning; digital workflow; craniofacial implants; guided implants surgery

\section{Introduction}

Orbital defects can arise from acquired or congenital anomalies. Acquired defects of the orbital location can be seen due to tumors and trauma, while congenital defects appear as the result of developmental anomalies. Exenteration of the eye is one of the most aggressive surgical approaches, which is usually seen after orbital tumor resection. The restoration of an exenteration defect is mostly dependent on the prosthetic options to improve the esthetics and quality of life of these patients [1-5]. With the introduction of endosseous implants, the prosthetic rehabilitation of exenteration orbital defects became less challenging, as they provide improved retention, support and stability of orbital prostheses $[3,6]$. However, improper planning and placement of these implants can 
have detrimental consequences on the long-term success and survival of implant-retained prostheses [7,8]. Studies have reported 35-75\% success rates upon 3-14 years of followup [9-13]. Success rates depend on multiple factors, such as the anatomic location, quality and quantity of bone, systemic health and dose of radiation therapy. In general, the bone in the orbital region is limited, composed of mainly compact bone with little or no marrow, which poses a challenge for the osseointegration of craniofacial implants in this location. Therefore, preoperative planning and intraoperative surgical guides have been increasingly stressed upon for orbital implants placement and the success of orbital implant-retained prostheses [14].

Digital planning systems have brought about revolution in the surgical and prosthetic fields [15]. Computer-aided design and computer-aided manufacturing systems (CAD/CAM) have been in use for implants placement for more than 15 years. By utilizing this 3D technology, customized surgical implant guides can be fabricated, which enables the preoperative planning data to be transferred for intraoperative use in precise implant placement [16]. The preoperative data for digital planning is usually collected either through the use of noncontact three-dimensional imaging such as computed tomography (CT), cone beam-computed tomography (CBCT) and magnetic resonance imagining (MRI) or through various laser scanners. According to Sarment et al. [17], the use of CAD/CAM surgical templates significantly increases the precision and accuracy of dental implant placement when compared with the conventional surgical guides. Furthermore, the use of CAD/CAM technology for craniofacial implants surgery has also been used recently with satisfactory clinical outcomes [18].

More recently, navigation systems have been introduced in craniofacial surgeries. These systems allow surgeons to control the position and movement of instruments with the help of medical images in multiplanar views. Navigation pointer or adapted instruments upon coming into contact with the patient identify the exact location within the radiographic image, giving the operator the ability to simultaneously navigate within the surgical field and virtual anatomical map [19]. With the introduction of navigation systems in the field of dental implantology, two approaches have been used to place implants: dynamic and static navigation. Dynamic navigation works with the help of 3D software, which enables the monitoring of bone drilling and subsequent implant placement in real time throughout the procedure $[20,21]$, while static navigation works through static surgical templates during bone drilling and implant placement.

CAD/CAM technology claims to reduce patient appointments, as well as the clinical and laboratory times of procedures, and reduce the steps of fabrication without compromising the clinical outcome. CAD/CAM systems have been used for the fabrication of surgical templates, models, molds, substructures, customized implants and guided implant surgeries for the prosthetic rehabilitation of orbital defects. The aim of this study is to gather the clinical data to respond to the following question: In patients with orbital defects, what are the technical and clinical applications of CAD/CAM technology for the preoperative planning, designing and manufacturing of orbital prostheses?

\section{Experimental Section}

A systematic review was executed according to the protocol based on all Preferred Reporting Items for Systematic Reviews and Meta-Analyses (PRISMA) [22] for the assessment of the PICO (patients (P), investigation (I), comparison (C) and outcome $(\mathrm{O})$ ) question.

Population: Patients with orbital defects.

Intervention: Applications of CAD/CAM technology for preoperative planning and the placement of craniofacial implants.

Comparison: Not applicable.

Outcome: Fabrication of orbital prostheses.

Therefore, the established question was adapted to the PIO question: "In patients with orbital defects $(\mathrm{P})$, what are the technical and clinical applications of CAD/CAM technology for craniofacial implant placement (I) and the manufacturing of orbital prostheses $(\mathrm{O})$ ?" 
This was done while also taking into account that comparison (C) was not applicable in this systematic review.

\subsection{Search Strategy}

The electronic search was conducted by entering a combination of the following terms: (Prostheses AND Planning AND Guide).

Prosthesis: (orbital prostheses OR eye prostheses OR silicone orbital prostheses) AND Planning: (CAD/CAM OR scanning OR digital OR software planning OR navigation OR 3D) AND Guide: (implants OR craniofacial implants OR extraoral implants OR surgical guide OR surgical template OR guided surgery OR printed guide OR navigation system).

\subsection{Eligibility Criteria}

Human clinical studies, published in the English language from January 2000 to July 2021, were included in this systematic review. The inclusion criteria involved randomized control trials, cohort studies, case control studies, case series and case reports involving the use of digital planning software for orbital craniofacial implants placement or the fabrication of orbital prostheses. The exclusion criteria were systematic reviews, a finite element analysis (FEA), animal studies, in vitro studies and case reports performed without digital planning software (Figure 1).

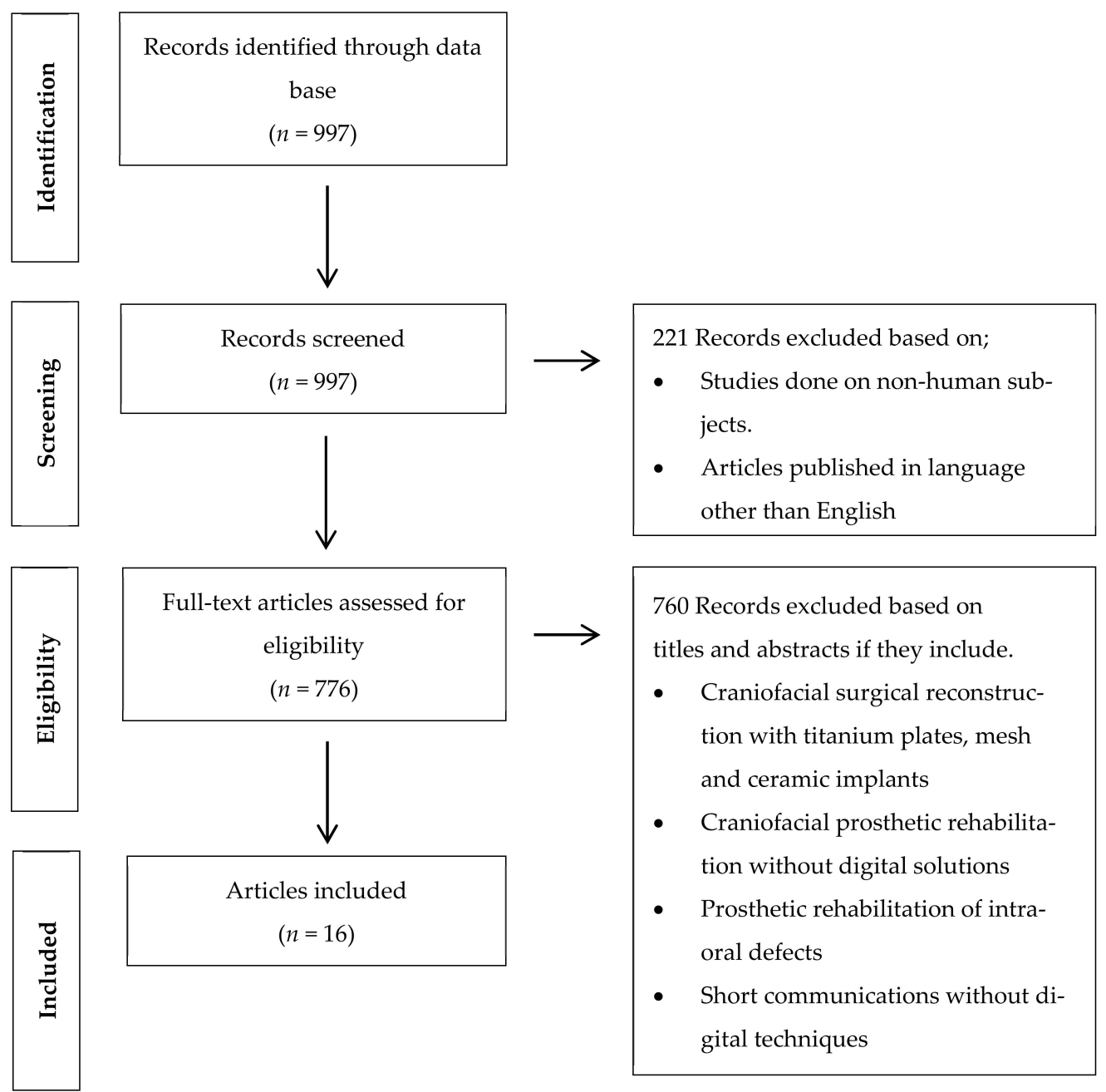

Figure 1. Flow chart of the studies selection process and screening methodology. 


\subsection{Source of Information}

An electronic search from January 2000 to July 2021 was conducted in The National Library of Medicine (MEDLINE/PubMed) database.

Moreover, a manual search of the following journals from January 2000 until July 2021 was also performed: The Journal of Oral Rehabilitation, The Journal of Prosthetic Dentistry, The Journal of Prosthodontics, The International Journal of Prosthodontics, The Journal of Prosthodontic Research, Clinical Oral Implants Research, The Journal of Oral Implantology, The International Journal of Oral and Maxillofacial Implants, International Journal of Oral and Maxillofacial Surgery, Journal of Oral and Maxillofacial Surgery, Journal of Cranio-maxillo-facial surgery, Journal of Stomatology, Oral and Maxillofacial Surgery and the British Journal of Oral and Maxillofacial Surgery, Implant Dentistry and Clinical Implant Dentistry and Related Research.

\subsection{Study Selection}

The studies were selected individually by two independent reviewers (W.T. and P.M.M.) through the titles and abstracts of all the identified studies, through the electronic search and further reading individually by the authors. The studies that appeared to fulfill the inclusion criteria, or those studies that had limited data in the title and abstract to reach a final decision, were gathered. Disagreements among the authors were resolved after discussion.

\subsection{Data Extraction}

The data from each included study was extracted according to the designed standard form: Author's name, year of publication, purpose of digital planning, preoperative data collection, software utilized, printing systems, printing materials, craniofacial implants systems and number of implants placed in each case (Table 1). Contact was made with the authors for possible missing data.

\subsection{Risk of Bias in Individual Studies}

Two independent reviewers (W.T. and P.M.M.) assessed the quality of the included studies. If there was any conflict of agreement regarding any paper, it was further assessed by a third reviewer (A.R.P.). For the assessment step, the critical tools of The Joanna Briggs Institute [23] (JBI) for case series and clinical case reports were used in accordance with the type of included articles. The bias was assessed through a list of 8 questions for case reports and 10 questions for case series, respectively. The questions are specified in Tables 2 and 3 regarding the risk of bias. Finally, an overall appraisal was made to determine if the risk of bias was low (included), high (excluded) or uncertain (more information needs to be sought). We considered it a high risk of bias if the answer "no" was $\geq 50 \%$, a low risk of bias if the answer "yes" was $\geq 50 \%$ and an uncertain risk of bias if the "unclear" answer was $\geq 50 \%$. 
Table 1. Digital planning for the prosthetic rehabilitation of orbital defects.

\begin{tabular}{|c|c|c|c|c|c|c|c|c|c|}
\hline Publications & $\begin{array}{l}\text { No. of } \\
\text { Cases }\end{array}$ & $\begin{array}{l}\text { Purpose of } \\
\text { Software } \\
\text { Planning }\end{array}$ & $\begin{array}{l}\text { Pre-op Data for Digital } \\
\text { Planning }\end{array}$ & Software & Printer/Miller & Printing Materials & $\begin{array}{l}\text { Navigation } \\
\text { System } \\
\text { (Yes/No) }\end{array}$ & $\begin{array}{l}\text { Location \& } \\
\text { No. of } \\
\text { Implants }\end{array}$ & Implants System \\
\hline $\begin{array}{l}\text { Zhang, X. et al., } \\
2010 \text { [14] }\end{array}$ & 1 & $\begin{array}{l}\text { Surgical template } \\
\text { for implants } \\
\text { placement }\end{array}$ & $\mathrm{CT}$ & $\begin{array}{c}\text { Ease Orbital Implant } \\
\text { Planning Software (EOIPlan) } \\
\text { (Guangdong Provincial } \\
\text { Hospital, First Affiliated } \\
\text { Hospital, Sun Yat-sen } \\
\text { University, Guangzhou, } \\
\text { China) }{ }^{1}\end{array}$ & $\begin{array}{l}\text { Rapid prototype; FDM } \\
\text { 400mc, Stratasys (Stratasys, } \\
\text { Eden Prairie, MN, USA) }\end{array}$ & NM & No & $\begin{array}{l}\text { Orbital bone } \\
\text { rim; } 3 \\
\text { implants }\end{array}$ & $\begin{array}{l}\text { Vistafix implant } \\
\text { system (Entific } \\
\text { Medical Systems) }\end{array}$ \\
\hline $\begin{array}{l}\text { Ciocca, L. et al., } \\
2014 \text { [25] }\end{array}$ & 1 & $\begin{array}{l}\text { Fabrication of } \\
\text { Orbital prosthesis } \\
\text { substructure and } \\
\text { mold }\end{array}$ & $\begin{array}{l}\text { MRI, Laser scan } \\
\text { (Desktop NextEngine; } \\
\text { NextEngine, Santa } \\
\text { Monica, CA, USA) }\end{array}$ & $\begin{array}{l}\text { Freeform Modeling Plus } \\
\text { software (3D Systems Inc., } \\
\text { Rock Hill, SC, USA) }{ }^{10}\end{array}$ & $\begin{array}{l}\text { RP machine (Phantom } \\
\text { Desktop Haptic device, } \\
\text { ClayTools system; } \\
\text { Sensable, Wilmington, MA, } \\
\text { USA) }\end{array}$ & Polyamide resin & No & No implants & No implants \\
\hline $\begin{array}{l}\text { Liu, H. et al., } \\
2019 \text { [26] }\end{array}$ & 1 & $\begin{array}{l}\text { Fabrication of } \\
\text { mold for orbital } \\
\text { prosthesis }\end{array}$ & $\begin{array}{l}\text { 3dMDface System } \\
\text { (3dMD LLC, Atlanta, } \\
\text { Georgia, USA), } 3 \text { shape } \\
\text { scanner (3 Shape scanner, } \\
\text { Copenhagen, Denmark) }\end{array}$ & $\begin{array}{l}\text { Geomagic studio 2014; (3D } \\
\text { Systems Inc., Rock Hill, SC, } \\
\text { USA) }{ }^{2}\end{array}$ & $\begin{array}{c}\text { 3D printer EOS } 500 \text { (EOS, } \\
\text { Krailling, Germany) }\end{array}$ & $\begin{array}{c}\text { polyamide (PA2200; } \\
\text { EOS) (EOS, } \\
\text { Krailling, Germany) }\end{array}$ & No & No implants & No implants \\
\hline $\begin{array}{l}\text { Yoshioka, F. } \\
\text { et al., } 2010 \text { [27] }\end{array}$ & 1 & $\begin{array}{l}\text { Fabrication of } \\
\text { mold }\end{array}$ & $\begin{array}{c}\text { VIVID } 910 \text { 3D } \\
\text { noncontact digitizer } \\
\text { (Konica Minolta, Osaka, } \\
\text { Japan) }\end{array}$ & $\begin{array}{l}\text { Softwares; Mimics (Mimics } \\
\text { Innovation Suite, Materialise, } \\
\text { Leuven, Belgium) }{ }^{5} \text { and } \\
\text { Magics, }{ }^{2} \text { (3D Systems Inc., } \\
\text { Rock Hill, SC, USA) }\end{array}$ & $\begin{array}{l}\text { 3D thermojet printer (Z510, } \\
\text { Z Corp, Cambridge, MA, } \\
\text { USA) }\end{array}$ & $\begin{array}{l}\text { Hybrid plaster: ZP } \\
\text { 150, (Z510, Z Corp, } \\
\text { Cambridge, MA, } \\
\text { USA) }\end{array}$ & No & No implant & No implant \\
\hline $\begin{array}{l}\text { Sabol, J. et al., } \\
\quad 2011[28]\end{array}$ & 1 & $\begin{array}{l}\text { Fabrication of 3D } \\
\text { model for orbital } \\
\text { prosthesis }\end{array}$ & $\begin{array}{l}\text { 3dMDface System } \\
\text { (3dMD LLC, Atlanta, } \\
\text { Georgia, USA) }\end{array}$ & $\begin{array}{l}\text { Magics version } 12.01 \text { (3D } \\
\text { Systems Inc., Rock Hill, SC, } \\
\text { USA) }{ }^{2}\end{array}$ & $\begin{array}{c}\text { Zprinter } 450 \text { (Z Corp, } \\
\text { Cambridge, MA, USA), } \\
\text { SLA 7000, a } \\
\text { Stereolithography } \\
\text { Apparatus (3D Systems, } \\
\text { Rock Hill, SC, USA). }\end{array}$ & $\begin{array}{l}\text { zp130 powder (3D } \\
\text { Systems Inc., Rock } \\
\text { Hill, SC, USA) }\end{array}$ & No & No implants & No implants \\
\hline
\end{tabular}


Table 1. Cont.

\begin{tabular}{|c|c|c|c|c|c|c|c|c|c|}
\hline Publications & $\begin{array}{l}\text { No. of } \\
\text { Cases }\end{array}$ & $\begin{array}{l}\text { Purpose of } \\
\text { Software } \\
\text { Planning }\end{array}$ & $\begin{array}{l}\text { Pre-op Data for Digital } \\
\text { Planning }\end{array}$ & Software & Printer/Miller & Printing Materials & $\begin{array}{l}\text { Navigation } \\
\text { System } \\
\text { (Yes/No) }\end{array}$ & $\begin{array}{l}\text { Location \& } \\
\text { No. of } \\
\text { Implants }\end{array}$ & Implants System \\
\hline $\begin{array}{l}\text { Eo, M. Y. et al., } \\
\quad 2020 \text { [29] }\end{array}$ & 1 & $\begin{array}{l}\text { Fabrication of } \\
\text { master cast }\end{array}$ & $\begin{array}{l}\text { CT scan, Morpheus 3D } \\
\text { Scanner }^{\circledR} \text { (Morpheus } \\
\text { Co., Ltd., Seoul, Korea) }\end{array}$ & $\begin{array}{l}\text { ZBrush }^{\circledR} \text { software (Pixologic } \\
\text { Inc., Los Angeles, CA, USA) }\end{array}$ & $\mathrm{NM}$ & $\mathrm{NM}$ & No & $\begin{array}{l}3 \text { implants in } \\
\text { the lateral } \\
\text { orbital rim of } \\
\text { the zygoma }\end{array}$ & $\begin{array}{l}\text { 4.0-mm-diameter } \\
\text { and 7.0-mm-long } \\
\text { Luna }{ }^{\circledR} \text { implants } \\
\text { (Shinhung Co., } \\
\text { Seoul, Korea) }\end{array}$ \\
\hline $\begin{array}{l}\text { Huang, Y.H. } \\
\text { et al., } 2016 \text { [30] }\end{array}$ & 1 & $\begin{array}{l}\text { Surgical template } \\
\text { for implants } \\
\text { placement, model } \\
\text { of patient's skull }\end{array}$ & $\begin{array}{c}\text { CBCT, Next Generation } \\
\text { 17-19, Imaging Sciences } \\
\text { International, Hat eld, } \\
\text { PA, USA) }\end{array}$ & $\begin{array}{l}\text { Mimics Materialise (Mimics } \\
\text { Innovation Suite, Materialise, } \\
\text { Leuven, Belgium) }{ }^{5}\end{array}$ & $\begin{array}{l}\text { uPrint SE Plus 3D Printer } \\
\text { (Stratasys, Eden Prairie, } \\
\text { MN, USA), ZPrinter } \\
\text { (ZPrinter 310 Plus (Z Corp, } \\
\text { Cambridge, MA, USA)) }\end{array}$ & $\begin{array}{c}\text { Acrylonitrile } \\
\text { butadiene styrene } \\
\text { plastic (ABS) }\end{array}$ & No & $\begin{array}{l}5 \text { implants } \\
\text { (four } 3 \mathrm{~mm} \\
\text { and one } 4 \\
\mathrm{~mm} \text { ) in the } \\
\text { right orbital } \\
\text { rim. (Lateral } \\
\text { orbital rim } \\
\text { location) }\end{array}$ & $\begin{array}{c}\text { Craniofacial } \\
\text { implants }\left(\text { Vista }{ }^{\circledR}\right. \\
\text { Prior Generation, } \\
\text { Cochlear }{ }^{\mathrm{TM}}, \\
\text { Sydney, NSW, } \\
\text { Australia) }\end{array}$ \\
\hline $\begin{array}{l}\text { Chiu, M. et al., } \\
\quad 2017 \text { [31] }\end{array}$ & 1 & $\begin{array}{l}\text { Fabrication of } \\
\text { mold }\end{array}$ & $\begin{array}{l}\text { Digital photographs of } \\
\text { patient }\end{array}$ & $\begin{array}{c}\text { Autodesk 123D (Autodesk, } \\
\text { San Rafael, CA, USA) }{ }^{9}, \\
\text { Digital sculpting software } \\
\text { (Z-Brush, Pixologic Inc., Los } \\
\text { Angeles, CA, USA) }\end{array}$ & $\mathrm{NM}$ & NM & No & No & No \\
\hline $\begin{array}{l}\text { Ciocca, L. et al., } \\
2010 \text { [33] }\end{array}$ & 1 & $\begin{array}{l}\text { Fabrication of } \\
\text { mold and } \\
\text { substructure }\end{array}$ & $\begin{array}{l}\text { Laser scan; NextEngine } \\
\text { Desktop 3D Scanner } \\
\text { (NextEngine, Santa } \\
\text { Monica, CA, USA) }\end{array}$ & $\begin{array}{c}\text { NextEngine ScanStudio } \\
\text { software (NextEngine, Santa } \\
\text { Monica, CA, USA) }{ }^{11}, \\
\text { Rapidform XOS software } \\
\text { (INUS Technology, Seoul, } \\
\text { Korea) }{ }^{8}\end{array}$ & $\begin{array}{c}\text { Stratasys 3D printer } \\
\text { (Stratasys, Eden Prairie, } \\
\text { MN, USA) }\end{array}$ & $\begin{array}{c}\text { Acrylonitrile } \\
\text { butadiene styrene } \\
\text { plastic (ABS) }\end{array}$ & No & No & No \\
\hline $\begin{array}{l}\text { Verma, S.N. } \\
\text { et al., } 2017 \text { [34] }\end{array}$ & 1 & $\begin{array}{l}\text { Image guided } \\
\text { surgical } \\
\text { navigation for } \\
\text { orbital implants } \\
\text { placement }\end{array}$ & CT scan & $\begin{array}{l}\text { Stryker, Intellect Cranial, } \\
\text { (Stryker Navigation system, } \\
\text { Kalamazoo, MI, USA) }{ }^{12}\end{array}$ & No & No & Yes & $\begin{array}{l}3 \text { implants in } \\
\text { right } \\
\text { superior } \\
\text { orbital rim. }\end{array}$ & $\mathrm{NM}$ \\
\hline
\end{tabular}


Table 1. Cont.

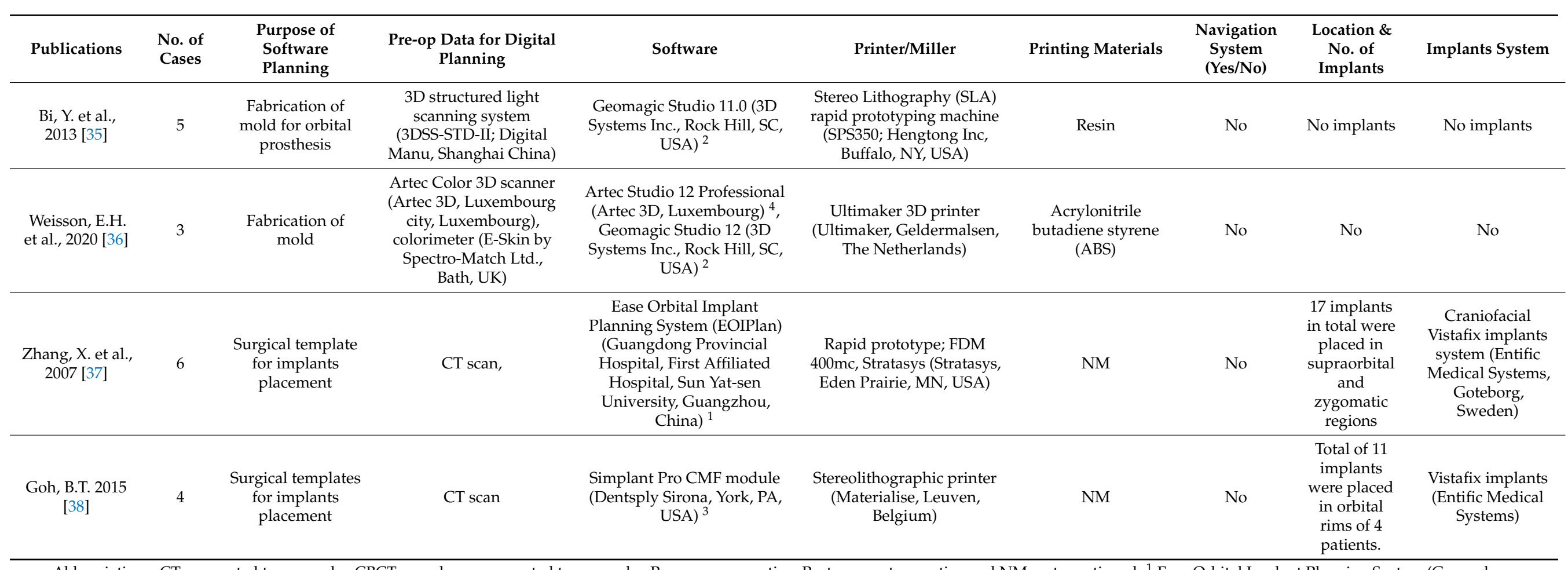

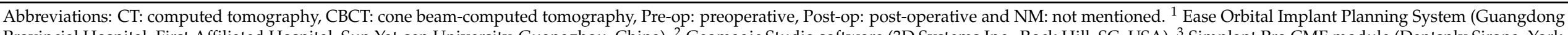

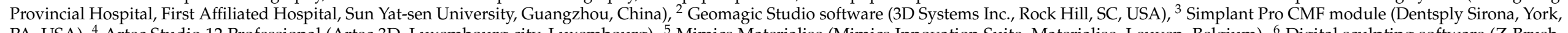

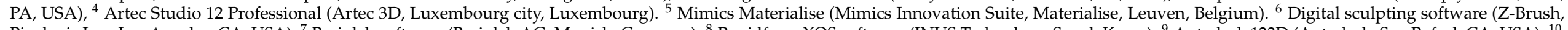

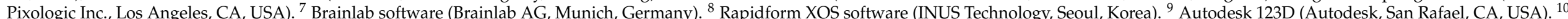

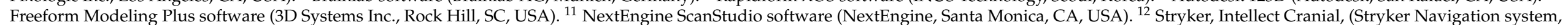
Kalamazoo, MI, USA). 
Table 2. Risk of bias for the case reports.

\begin{tabular}{|c|c|c|c|c|c|c|c|}
\hline \multirow[b]{2}{*}{ Assessment } & \multicolumn{7}{|c|}{ Author and Year } \\
\hline & $\begin{array}{l}\text { Zhang, X. } \\
\text { et al., } \\
2010 \text { [14] }\end{array}$ & $\begin{array}{c}\text { Li, S. } \\
\text { et al., } \\
2015 \text { [24] }\end{array}$ & $\begin{array}{l}\text { Ciocca, L. } \\
\text { et al., } \\
2014 \text { [25] }\end{array}$ & $\begin{array}{c}\text { Liu, H. } \\
\text { et al., } \\
2019[26]\end{array}$ & $\begin{array}{l}\text { Yoshioka, } \\
\text { F. et al., } \\
2010[27]\end{array}$ & $\begin{array}{l}\text { Sabol, J. } \\
\text { et al., } \\
2011 \text { [28] }\end{array}$ & $\begin{array}{l}\text { Eo, M.Y. } \\
\text { et al., } \\
2020[29]\end{array}$ \\
\hline $\begin{array}{l}\text { Were patient's demographic characteristics } \\
\text { clearly described? }\end{array}$ & Yes & Yes & Yes & Yes & Yes & Yes & Yes \\
\hline $\begin{array}{l}\text { Was the patient's history clearly described and presented } \\
\text { as a timeline? }\end{array}$ & Yes & No & No & No & Yes & Yes & Yes \\
\hline $\begin{array}{l}\text { Was the current clinical condition of the patient on } \\
\text { presentation clearly described? }\end{array}$ & Yes & Yes & Yes & Yes & Yes & Yes & Yes \\
\hline $\begin{array}{l}\text { Were diagnostic tests or assessment methods and the } \\
\text { results clearly described? }\end{array}$ & No & No & No & No & No & No & Unclear \\
\hline $\begin{array}{l}\text { Was the intervention(s) or treatment procedure(s) } \\
\text { clearly described? }\end{array}$ & Yes & Yes & Yes & Yes & Yes & Yes & Yes \\
\hline $\begin{array}{l}\text { Was the post-intervention clinical condition } \\
\text { clearly described? }\end{array}$ & Yes & Yes & Yes & Yes & Yes & Yes & Yes \\
\hline $\begin{array}{l}\text { Were adverse events (harms) or unanticipated events } \\
\text { identified and described? }\end{array}$ & No & No & No & No & No & Yes & No \\
\hline Does the case report provide takeaway lessons? & Yes & Yes & Yes & Yes & Yes & Yes & Yes \\
\hline \multirow[t]{2}{*}{ Overall appraisal } & Included & Included & Included & Included & Included & Included & Included \\
\hline & $\begin{array}{l}\text { Huang, } \\
\text { Y.H. et al., } \\
2016[30]\end{array}$ & $\begin{array}{c}\text { Chiu, M. } \\
\text { et al., } \\
2017 \text { [31] }\end{array}$ & $\begin{array}{l}\text { Choi, K.J. } \\
\text { et al., } \\
2016 \text { [32] }\end{array}$ & \multicolumn{2}{|c|}{$\begin{array}{l}\text { Ciocca, L. et al., } \\
2010 \text { [33] }\end{array}$} & \multicolumn{2}{|c|}{$\begin{array}{c}\text { Verma, S.N. et al., } \\
2017 \text { [34] }\end{array}$} \\
\hline $\begin{array}{l}\text { Were patient's demographic characteristics } \\
\text { clearly described? }\end{array}$ & Yes & Yes & Yes & \multicolumn{2}{|c|}{ Yes } & \multicolumn{2}{|c|}{ Yes } \\
\hline $\begin{array}{l}\text { Was the patient's history clearly described and presented } \\
\text { as a timeline? }\end{array}$ & Yes & Yes & Yes & \multicolumn{2}{|c|}{ Yes } & \multicolumn{2}{|c|}{ No } \\
\hline $\begin{array}{l}\text { Was the current clinical condition of the patient on } \\
\text { presentation clearly described? }\end{array}$ & Yes & Yes & Yes & \multicolumn{2}{|c|}{ Yes } & \multicolumn{2}{|c|}{ Yes } \\
\hline $\begin{array}{l}\text { Were diagnostic tests or assessment methods and the } \\
\text { results clearly described? }\end{array}$ & No & No & No & \multicolumn{2}{|c|}{ Unclear } & \multicolumn{2}{|c|}{ No } \\
\hline $\begin{array}{l}\text { Was the intervention(s) or treatment procedure(s) } \\
\text { clearly described? }\end{array}$ & Yes & Yes & Yes & \multicolumn{2}{|c|}{ Yes } & \multicolumn{2}{|c|}{ Yes } \\
\hline $\begin{array}{l}\text { Was the post-intervention clinical condition } \\
\text { clearly described? }\end{array}$ & Yes & Yes & Yes & \multicolumn{2}{|c|}{ Yes } & \multicolumn{2}{|c|}{ Yes } \\
\hline $\begin{array}{l}\text { Were adverse events (harms) or unanticipated events } \\
\text { identified and described? }\end{array}$ & No & No & Yes & \multicolumn{2}{|c|}{ No } & \multicolumn{2}{|c|}{ No } \\
\hline Does the case report provide takeaway lessons? & Yes & Yes & Yes & \multicolumn{2}{|c|}{ No } & \multicolumn{2}{|c|}{ Yes } \\
\hline Overall appraisal & Included & Included & Included & \multicolumn{2}{|c|}{ Included } & \multicolumn{2}{|c|}{ Included } \\
\hline
\end{tabular}

Table 3. Risk of bias for the case series.

\begin{tabular}{|c|c|c|c|c|}
\hline \multirow[b]{2}{*}{ Assessment } & \multicolumn{4}{|c|}{ Author and Year } \\
\hline & $\begin{array}{l}\text { Bi, Y. et al., } \\
2013 \text { [35] }\end{array}$ & $\begin{array}{l}\text { Weisson, E.H. } \\
\text { et al., } 2020 \text { [36] }\end{array}$ & $\begin{array}{l}\text { Zhang, } X . \\
\text { et al., } 2007[37]\end{array}$ & $\begin{array}{l}\text { Goh, B.T. } \\
2015[38]\end{array}$ \\
\hline Were there clear criteria for inclusion in the case series? & Yes & Yes & Yes & Yes \\
\hline $\begin{array}{l}\text { Was the condition measured in a standard, reliable way for all } \\
\text { participants included in the case series? }\end{array}$ & Yes & Unclear & Yes & Yes \\
\hline $\begin{array}{l}\text { Were valid methods used for identification of the condition for } \\
\text { all participants included in the case series? }\end{array}$ & Unclear & Yes & Unclear & Yes \\
\hline Did the case series have consecutive inclusion of participants? & Yes & Yes & Yes & Yes \\
\hline
\end{tabular}


Table 3. Cont

\begin{tabular}{|c|c|c|c|c|}
\hline \multirow[b]{2}{*}{ Assessment } & \multicolumn{4}{|c|}{ Author and Year } \\
\hline & $\begin{array}{l}\text { Bi, Y. et al., } \\
2013 \text { [35] }\end{array}$ & $\begin{array}{l}\text { Weisson, E.H. } \\
\text { et al., } 2020 \text { [36] }\end{array}$ & $\begin{array}{l}\text { Zhang, X. } \\
\text { et al., } 2007[37]\end{array}$ & $\begin{array}{l}\text { Goh, B.T. } \\
2015[38]\end{array}$ \\
\hline Did the case series have complete inclusion of participants? & Yes & Yes & Yes & Yes \\
\hline $\begin{array}{l}\text { Was there clear reporting of the demographics of the } \\
\text { participants in the study? }\end{array}$ & Yes & Yes & Yes & Yes \\
\hline Was there clear reporting of clinical information of the participants? & Unclear & Yes & Unclear & Yes \\
\hline Were the outcomes or follow up results of cases clearly reported? & Yes & Yes & Unclear & Yes \\
\hline $\begin{array}{l}\text { Was there clear reporting of the presenting site(s)/clinic(s) } \\
\text { demographic information? }\end{array}$ & Yes & Yes & Yes & Yes \\
\hline Overall appraisal & Included & Included & Included & Included \\
\hline
\end{tabular}

\section{Results}

\subsection{Study Selection}

The above-mentioned term was searched through the PubMed database. The flowchart summarized the literature search and selection process in Figure 1. Since the majority of digital advancements for digital planning and printing systems have been seen in the last two decades, the initial search yielded 997 studies with a time filter (January 2000-July 2021). Two hundred and twenty-one studies were excluded by using language (English) and human studies filters. Furthermore, 776 studies were screened on the basis of the titles and abstracts by following the inclusion and exclusion criteria; therefore, an additional 760 studies were excluded based on their rehabilitation techniques and study design (craniofacial reconstruction with titanium plates, ceramic implants and mesh plates, prosthetic rehabilitation of orbital defects without digital solutions and the prosthetic restoration of intraoral defects and ocular implants). After reading full-text papers, a total of 16 studies were included that involved a total of 30 cases planned and executed with digital planning software for the prosthetic rehabilitation of orbital defects (Table 1). Due to the included studies, a quality and data heterogeneity meta-analysis could not be performed.

\subsection{Study Characteritics}

\subsubsection{Applications of CAD/CAM Technology for Surgical and Prosthetic Purposes}

The included literature mentioned the following purposes for using digital software to virtually plan and execute surgical and prosthetic procedures: mold fabrication for silicone (13 cases), surgical templates (12 cases), the designing of substructures ( 2 cases), the fabrication of models ( 2 cases) and dynamic image-guided surgical navigation ( 2 cases).

\subsubsection{Preoperative Record for Digital Planning}

Digital preoperative planning required the following records for surgical and prosthetic procedures: CT scans (15 cases), 3D structured light scanning system (3DSS-STD-II; Digital Manu, Shanghai China) (5 cases), Artec Color 3D scanner (Artec 3D, Luxembourg) (3 cases), Laser scanner NextEngine Desktop 3D Scanner (NextEngine, Santa Monica, CA, USA) (2 cases), 3dMDface System (3dMD LLC, Atlanta, Georgia, USA), (2 cases), MRI (1 case), CBCT (1 case), Morpheus 3D Scanner (Morpheus Co., Ltd., Seoul, Korea) (1 case), 3 shape scanner (3 Shape, Copenhagen, Denmark) and Laser scanner VIVID 910 3D noncontact digitizer (Konica Minolta, Osaka, Japan) (1 case).

\subsubsection{Preoperative Record for Digital Designing}

The digital software utilized by the included studies were Ease Orbital Implant Planning EOIPlan software (Guangdong Provincial Hospital, First Affiliated Hospital, Sun Yat-sen University, Guangzhou, China) (eight cases), Geomagic software (3D Systems, 
Rock Hill, SC, USA) (eight cases), Simplant software (Dentsply Sirona, York, PA, USA) (four cases), Artec Studio 12 Professional (Artec 3D, Luxembourg) (three cases), Mimics software (Mimics Innovation Suite, Materialise, Leuven, Belgium) (two cases), Digital sculpting software Zbrush software (Pixologic Inc., Los Angeles, CA, USA) (two cases), Brainlab software (Brainlab AG, Munich, Germany) (one case), Rapidform XOS software (INUS Technology, Seoul, Korea) (one case), Autodesk 123D (Autodesk, San Rafael, CA, USA) (one case), Freeform ClayTools software (Freeform, NC, USA) (one case) and NextEngine ScanStudio software (NextEngine, Santa Monica, CA, USA) (one case).

\subsubsection{Printing Systems Utilized for Surgical and Prosthetic Phases}

Fused deposition modeling (FDM) and stereolithography (SLA) were the two main types of digital printing systems utilized following the digital planning phase for surgical and prosthetic purposes. Fused deposition modeling printers (FDM) Stratasys 400mc (Stratasys, Eden Prairie, MN, USA), ZPrinter ${ }^{\circledR} 310$ Plus (Z Corp, Cambridge, MA, USA), Zprinter 450 (Z Corp, Cambridge, MA, USA), Ultimaker 3D printer (Ultimaker, Geldermalsen, The Netherlands) and 3D thermojet printer Z510 (Z Corp, Cambridge, MA, USA) were used for seven cases. The printing material used for these cases was acrylonitrile butadiene styrene plastic (ABS). Stereolithography (SLA) printers SLA 7000 (3D Systems, NC, USA), rapid prototyping machine SPS350 (Computer aided technology, Buffalo, NY, USA) and 3D printer EOS P500 (EOS, Krailling, Germany) were used for 10 cases. The printing material used for SLA-based printing systems was polyamide.

\subsubsection{Guided Implants Surgery}

A total of 44 craniofacial implants were placed in 30 cases after the digital planning and designing of surgical templates. Out of the total 44 implants, 38 implants belonged to the Vistafix implants system (Entific Medical Systems, Goteborg, Sweden), while three implants were used from the Luna implants system (Shinhung Co., Seoul, Korea). Dynamic surgical navigation systems Brainlab (Brainlab AG, Munich, Germany) and Stryker (Stryker Intellect Cranial) were used to guide five implants in two cases.

\subsection{Risks of Bias in Individual Studies}

The JBI criteria was followed to assess the risk of bias of the individual studies. As illustrated by Table 2, the case reports authored by Zhang, X. et al., 2010 [14], Li, S. et al., 2015 [24], Ciocca, L. et al., 2014 [25], Liu, H. et al., 2019 [26], Yoshioka, F. et al., 2010 [27], Sabol, J. et al., 2011 [28], Eo, M.Y. et al., 2020 [29], Huang, Y.H. et al., 2016 [30], Chiu, M. et al., 2017 [31], Choi, K.J. et al., 2016 [32], Ciocca, L. et al., 2010 [33] and Verma, S.N. et al., 2017 [34] showed a low risk of bias. Meanwhile, Table 3 showed that the case series authored by Bi, Y. et al., 2013 [35], Weisson, E.H. et al., 2020 [36], Zhang, X. et al., 2007 [37] and Goh, B.T. 2015 [38] presented a low risk of bias.

In Figure 2, it can be observed that most studies had a low risk of bias $\leq 50 \%$, except for the question, "Were adverse events (harms) or unanticipated events identified and described?", for which more than $75 \%$ of the studies did not mention any adverse event or unanticipated events. For one question, "Were the diagnostic tests or assessment methods and the results clearly described?", more than $50 \%$ of the studies did not clearly mention the diagnostic tests or assessment methods or results of the investigations.

Furthermore, Figure 3 illustrates the risk of bias for four case series studies. Most questions were in favor of a low risk of bias. For two questions, the details were unclear: "Were valid methods used for identification of the condition for all participants included in the case series?" and "Was there clear reporting of clinical information of the participants?". Furthermore, it was not possible to perform a meta-analysis due to the quality of the included studies, case series and case reports. 
Does the case report provide takeaway lessons? Were adverse events (harms) or unanticipated events identified and described?

Was the post-intervention clinical condition clearly described? Was the intervention(s) or treatment procedure(s) clearly described? Were diagnostic tests or assessment methods and the results clearly described?

Was the current clinical condition of the patient on presentation clearly described?

Was the patient's history clearly described and presented as a timeline?

Were patient's demographic characteristics clearly described?

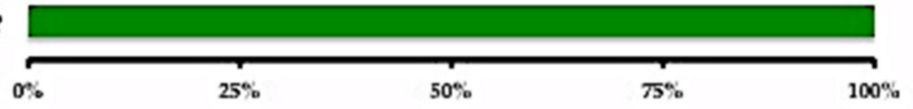
$=\mathrm{N} / \mathrm{A}$
Unclear
日 Low
a High

Figure 2. Risk of bias across the included studies for case reports.

Was there clear reporting of the presenting site(s)/clinic(s) demographic information?

Were the outcomes or follow up results of cases clearly reported?

Was there clear reporting of clinical information of the participants?

Was there clear reporting of the demographics of the participants in the study?

Did the case series have complete inclusion of participants?

Did the case series have consecutive inclusion of participants?

Were valid methods used for identification of the condition for all participants included in the case series?

Was the condition measured in a standard, reliable way for all participants included in the case series?

Were there clear criteria for inclusion in the case series?
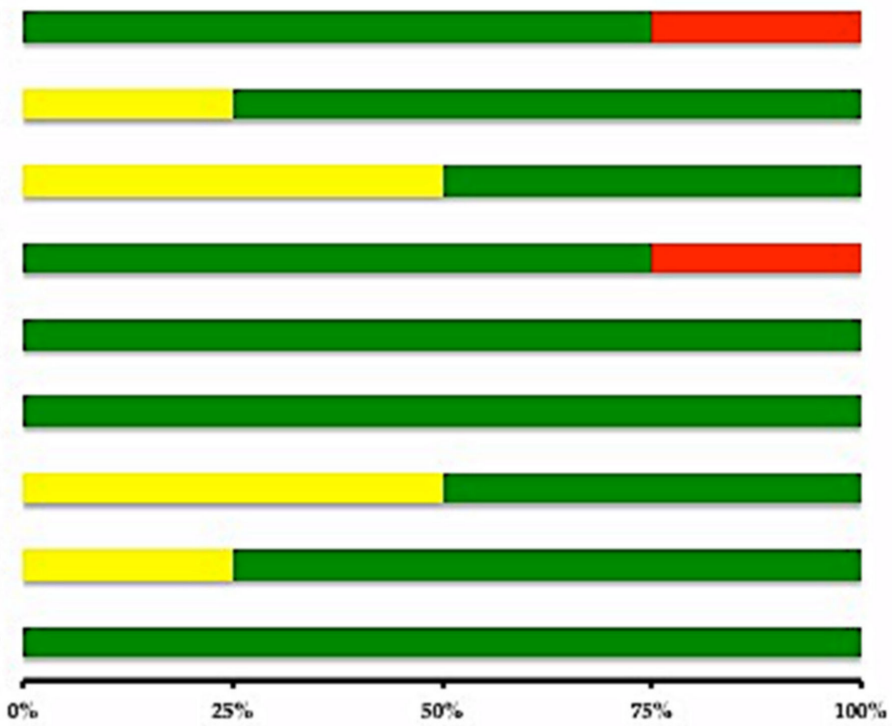

N N/A Unclear a Low a High

Figure 3. Risk of bias for the case series.

\section{Discussion}

Digital planning and designing systems have brought about revolution in dentistry during the last couple of decades. Intraoral implants have been virtually planned and used in computer-guided surgeries since $1997[39,40]$. These digital technology advancements further led to the guided surgeries of craniofacial implants and assisted clinicians and dental technicians in exploring the possibilities of the designing and printing of molds, retentive substructures, customized implants, models, digital wax-ups and prosthesis fabrication [18]. With CAD/CAM application, the surgical procedures became more predicable and reduced 
the clinical and laboratory times of the surgical and prosthetic steps, reduced the number of patient appointments and provided the patients a chance to virtually visualize the expected outcome before undergoing irreversible procedures [18]. Therefore, the aim of this paper was to gather clinical studies about the various applications of CAD/CAM technology for craniofacial implants placement and the fabrication of orbital prostheses.

Three-dimensional imaging has added an extra dimension to the conventionally available preoperative radiographs with the additional advantage of low radiation doses and detailed information about the bone quantity, bone volume and proximity of adjacent anatomical structures [16,41]. The data from magnetic resonance imaging (MRI), computed tomography (CT) or cone beam-computed tomography (CBCT) can be utilized for preoperative planning by processing through various digital software $[42,43]$. Therefore, the obtained data from 3D systems facilitates the preoperative planning to guide implants into the most favorable position and angulation without compromising the adjacent critical anatomical structures and prosthetic plan [42-45]. Among different factors, the slice thickness, pitch, tube current, voltage, image's slices reconstruction algorithm, slight patient movement and potential artifacts arising from a metal prosthesis can induce errors [46]. The slice thickness has a direct effect on the volume measurements; therefore, it should be kept $<1.25 \mathrm{~mm}[47,48]$. In total, four included studies mentioned the slice thickness of CT scans ranging from 1 to $1.25 \mathrm{~mm}[14,32,37,38]$. Meanwhile, the voxel size has influence on the quality, scanning and reconstruction time of CBCT images. A total of two included studies mentioned voxel sizes of $0.3 \times 0.3 \times 0.3 \mathrm{~mm}$ and $0.3 \times 0.3 \times 2 \mathrm{~mm}$, respectively [30,37].

The integration of laser scans with $3 \mathrm{D}$ radiographic imaging introduced the possibility of computer-guided surgeries for implants placement [21,49]. By the incorporation of these two entities in designing software, surgeons and prosthodontists are able to plan computerguided surgeries in chronological sequence (prosthesis-driven implants placement), from prosthetic planning downwards to the proposed implant position and angulation [50]. In this study, 28 cases were executed by using CT scans, CBCT, MRI and laser scanners; out of which, three cases were planned by the combined use of laser scans and 3D radiographic images for preoperative planning.

Digital planning is dependent on computer-aided design systems, which utilize different software to improve the accuracy of implants placement, designing of molds and models, implant retentive attachments, frameworks, customized implants and provisional and definitive prostheses. In this study, Ease Orbital Implant Planning EOIPlan software and Simplant Pro software were used in a total for 12 cases to plan implant placements in orbital rims. Orbital endosteal implants were guided into the 6:00, 7:00, 9:00, 10:00 and 11:00 O'clock positions for the right orbital rim and 1:00, 2:00, 4:00, 5:00 and 6:00 O'clock positions for the left orbital rim [14,30,37]. Geomagic studio, Artec Studio, Mimics, Zbrush, Rapidform XOS, Autodesk 123D, Freeform ClayTools and NextEngine ScanStudio designing software were used in 16 cases to design molds, models and substructures for silicone packing and orbital prostheses, respectively.

Computer-aided designing (CAD) subsequently leads to computer-aided manufacturing (CAM) to convert the virtual planning and designing into reality by printing models, wax-ups, molds, surgical templates or direct prostheses through the use of fused deposition modeling (FDM) or stereolithography (SLA) based systems [51-55]. In the FDM method, a plastic filament is heated and extruded through an extrusion head on the deposition surface. The extruded plastic gets hard as soon as it is deposited due to the controlled temperature of the air. In this way, successive layers of the deposited material build a physical model. In order to build more complex physical models, accessary extrusion heads are required [53]. FDM technology uses polymers such as polycarbonates, acrylonitrile butyro styrene (ABS) and polysulfones, while the stereolithography method utilizes ultraviolet light to cure the photosensitive resin. Upon each layer of deposition, the ultraviolet light cure, in this way, ultimately builds up the desired complex structure upon successive layers and photopolymerization [53]. SLA-based printing systems use a monomer resin, which, 
upon photopolymerization, converts into a polymer. FDM printers are mainly used to manufacture models for preoperative planning, molds, provisional crowns and bridges, wax-ups and customized bite registrations, while SLA printers are used to manufacture surgical templates for guided implants surgeries [54]. Each method has its own advantages and disadvantages [54,55]. (Table 4). In the present review, FDM printers were used for seven cases. Acrylonitrile butyro styrene (ABS) was the material used to print molds and surgical templates in all seven cases, while SLA printers were used for 10 cases, and the printing material of choice was polyamide resin.

Table 4. Comparison between stereolithography (SLA) and fused deposition modeling and their applications (FDM) [17,51-55].

\begin{tabular}{|c|c|c|}
\hline & Stereolithography (SLA) & Fused Deposition Modeling (FDM) \\
\hline Materials for printing & Resins & $\begin{array}{l}\text { Acrylonitrile Butyro Styrene (ABS) } \\
\text { Calcium phosphate based material } \\
\text { Polycarbonates } \\
\text { Polyphenylsulfones } \\
\text { Nylon }\end{array}$ \\
\hline Advantages & $\begin{array}{l}\text { Short working time } \\
\text { High product resolution } \\
\text { No deformation } \\
\text { More efficient for complex models }\end{array}$ & $\begin{array}{l}\text { Relatively cheaper } \\
\text { Post-processing no chemicals }\end{array}$ \\
\hline Disadvantages & $\begin{array}{c}\text { Limited mechanical strength (mechanical strength } \\
\text { depends on the viscosity of resin used) } \\
\text { Irritant } \\
\text { Relatively expensive }\end{array}$ & $\begin{array}{l}\text { Long working time } \\
\text { Low product resolution } \\
\text { Limited shape complexity } \\
\text { Gradual deformation }\end{array}$ \\
\hline Thickness of layer & $0.05-0.015 \mathrm{~mm}$ & $0.5-0.127 \mathrm{~mm}$ \\
\hline $\begin{array}{l}\text { Possible applications for facial } \\
\text { prosthesis fabrication }\end{array}$ & $\begin{array}{l}\text { Surgical templates for computer guided surgeries } \\
\text { Retentive substructures }\end{array}$ & $\begin{array}{c}\text { Models after surface scans } \\
\text { Molds } \\
\text { Wax-ups } \\
\text { Provisional prosthesis }\end{array}$ \\
\hline
\end{tabular}

A total of 44 craniofacial implants were placed in 30 cases after the digital planning and designing of surgical templates. Due to the anatomical morphology of the orbital cavity and better biomechanical support, most studies mentioned three implants for an orbital implant-retained prosthesis [37]. Furthermore, magnet retentive attachments were preferred over clip bar attachments for the retention of orbital prostheses due to the ease of insertion and removal of prostheses and access for hygiene maintenance by the patients [38].

The CAD/CAM systems demonstrated the predictable results when rehabilitating patients with orbital defects in numerous studies (Table 5). Digital planning and designing software have enabled the clinical and technical staff to virtually plan cases and discuss the expected outcome with patients prior to invasive surgical procedures. Following the collection of preoperative data, CAD/CAM systems help to virtually plan, design and manufacture molds for silicone prostheses, the direct printing of silicone prostheses and surgical templates for craniofacial implant placement, as illustrated in Figure 4. Additionally, the literature also showed that CAD/CAM systems enable full digital workflows for reasonable times and costs (Table 6). According to Weisson, E.H. et al., 2020 [36], the digital workflow for an orbital prosthesis took $46 \mathrm{~h}$; out of which, $16 \mathrm{~h}$ were spent on printing the digital mold, which could be dramatically reduced by newer 3D printers. Sixteen hours were spent on the casting process for silicone at room temperature, which could also be reduced by adjusting the room temperature or using silicone material with less vulcanization time. Bi, Y. et al., 2013 [35] claimed that the whole digital workflow for an orbital prosthesis took $18.5 \mathrm{~h}$ from data acquisition to delivery of the prosthesis. Furthermore, a systematic review from Tanveer, W. et al. [18] also mentioned the digital workflow times of different case studies, which were found to be in the range of $12-21 \mathrm{~h}$. 
However, CAD/CAM systems do pose the limitations of skilled technical staff and expensive equipment hindering their use in many parts of the world. The printing of a direct silicone prosthesis and color matching are other limitations that might be resolved with further digital advancements in the near future.

Table 5. Enlisted are the clinical outcomes, recommendation and limitations mentioned in the included clinical studies.

\begin{tabular}{|c|c|c|c|}
\hline Included Articles & Outcome & Recommendations & Limitations \\
\hline Zhang, X. et al., 2010 [14] & $\begin{array}{l}\text { According to the authors, the } \\
\text { digital surgical template was } \\
\text { precisely designed for specific } \\
\text { surface topography or orbital } \\
\text { bone, therefore the template } \\
\text { was extremely stable and no } \\
\text { external fixation was required. }\end{array}$ & $\begin{array}{l}\text { Magnetic retention was } \\
\text { recommended for orbital } \\
\text { prosthesis due to the ease of } \\
\text { placement and removal } \\
\text { without compromising } \\
\text { retention of prosthesis. }\end{array}$ & - \\
\hline Li, S. et al., 2015 [24] & $\begin{array}{l}\text { The biggest measurement error } \\
\text { was less than } 0.3 \mathrm{~mm} \text { and the } \\
\text { variance was less than } 0.03 \text {. The } \\
\text { system provided the simulated } \\
\text { rehabilitation images, which } \\
\text { were helpful in } \\
\text { preoperative planning. }\end{array}$ & $\begin{array}{l}\text { According to surgical team } \\
\text { this error was claimed to be } \\
\text { acceptable and satisfies the } \\
\text { clinical requirements } \\
\text { regarding orbital } \\
\text { implants placement. }\end{array}$ & - \\
\hline Ciocca, L. et al., 2014 [25] & $\begin{array}{l}\text { Through this technique it was } \\
\text { possible to reduce the thickness } \\
(\leq 1 \mathrm{~mm}) \text { within } 1.5 \mathrm{~cm} \text { area } \\
\text { along the margins with } \\
\text { progressive increase in } \\
\text { thickness in bulk area of } \\
\text { silicone. Furthermore, this } \\
\text { technique enabled the } \\
\text { connection of eyeglasses and } \\
\text { prosthesis with the help of } \\
\text { digitally designed substructure, } \\
\text { which enhanced the retention. }\end{array}$ & - & $\begin{array}{l}\text { According to the authors, the } \\
\text { availability of CAD skilled } \\
\text { technician can be limited. } \\
\text { Furthermore, Closure of } \\
\text { oculo-facial defect by the help } \\
\text { of myocutaneous flap could } \\
\text { be a prosthetic limitation due } \\
\text { to the degree of difficulty in } \\
\text { adapting the thin margins of } \\
\text { prosthesis to mobile surface of } \\
\text { flap during the movement } \\
\text { of cheek. }\end{array}$ \\
\hline
\end{tabular}

The use of intraoral scanner can reproduce skin surface texture therefore authors claimed that additional manual sculpturing is not necessary.
The used technique is applicable to unilateral orbital defects.
The photo mapping function of mimics enabled confirmation of the external profile and position of pupil on designed model, Yoshioka, F. et al., 2010 [27] which was not possible to locate accurately through CT scan or convectional impression as patient need to close the eyes.

3D photography technique provided an STL model and 3D printed model for fabrication of

Sabol, J. et al., 2011 [28] orbital prosthesis. There were no ultimate differences in the fit of orbital prostheses fabricated on these models.

\section{This report presented} non-contact laser scanning method, which was clammed to be safer than CT scan as the patient will not be exposed to unnecessary radiation dose

\section{Authors recommended the} fabrication of intraoral prosthesis before the orbital prosthesis, as the contours of skin should be stable before capturing the image.
The limitations stated were the high cost of CAD/CAM systems and inability to match the color with adjacent skin. 
Table 5. Cont

\begin{tabular}{|c|c|c|c|}
\hline Included Articles & Outcome & Recommendations & Limitations \\
\hline Eo, M.Y. et al., 2020 [29] & $\begin{array}{l}\text { The combination of 3D scanning } \\
\text { with digital planning and } \\
\text { reconstruction resulted in } \\
\text { accurate orbital prosthesis in } \\
\text { short time. The patient had } \\
\text { reported excellent satisfaction } \\
\text { for esthetics and stability of } \\
\text { orbital prosthesis. The ability to } \\
\text { reproduce major mold resulted } \\
\text { in accurate silicone morphology. }\end{array}$ & - & $\begin{array}{l}\text { Authors highlighted the } \\
\text { limitation of silicone bonding } \\
\text { with metal components, using } \\
\text { plastic clay resin. }\end{array}$ \\
\hline Huang, Y.H. et al., 2016 [30] & $\begin{array}{l}\text { The surgical guide obtained } \\
\text { after digital planning was found } \\
\text { to resist any movement upon } \\
\text { seating, which indicated } \\
\text { accurate fitting between the } \\
\text { bone and surgical guide. } \\
\text { Furthermore, surgical guide } \\
\text { reduced the operating time. }\end{array}$ & - & $\begin{array}{l}\text { According to the authors, time } \\
\text { and cost spent for designing } \\
\text { and production of surgical } \\
\text { template was favorable but } \\
\text { more detailed time and cost } \\
\text { comparison will give better } \\
\text { understanding of cost } \\
\text { effectiveness of } \\
\text { surgical templates. }\end{array}$ \\
\hline Chiu, M. et al., 2017 [31] & $\begin{array}{l}\text { The presented technique } \\
\text { utilized digital camera instead } \\
\text { of CT/MRI, which reduced the } \\
\text { cost of data acquisition }\end{array}$ & $\begin{array}{l}\text { 3D photography was } \\
\text { recommended in place of CT } \\
\text { scans as it reduced the } \\
\text { unnecessary radiation dose } \\
\text { exposure and gives color } \\
\text { images which are important } \\
\text { for maxillofacial prosthesis }\end{array}$ & $\begin{array}{l}\text { The limitations expressed by } \\
\text { authors were the need of } \\
\text { specialized skills and the cost } \\
\text { of digital printers, which } \\
\text { might not be available in rural } \\
\text { location. Furthermore, it was } \\
\text { highlighted that 3D printing } \\
\text { of medical grade silicone is } \\
\text { not available }\end{array}$ \\
\hline
\end{tabular}

Image guided system was used for 3 cases. In patients 1 and 2, implants were real time guided even after extensive soft tissue debridement. For patient 3 , alternative implant site with adequate amount of bone was successfully identified and implant was guided in place through image-guided system.

The CAD/CAM technique along with "Ear \& Nose Library" dictated the fabrication

Ciocca, L. et al., 2010 [33] of provisional orbital prosthesis, which helped in immediate recovery following ablative cancer surgery and improved the quality of life of patient.
Authors suggested indications of image guided implants placement in head and neck cancer patients, which present altered anatomy, inadequate amount of bone and prior free flap reconstruction.

Immediate recovery from this provisional prosthesis is useful after ablative surgery. Titanium framework was recommended to support the facial prosthesis instead of ABS framework to reduce the bulk and improve the rigidity of attachment. 
Table 5. Cont.

\begin{tabular}{ll}
\hline \multicolumn{1}{c}{ Included Articles } & \multicolumn{1}{c}{ Outcome } \\
\hline & $\begin{array}{l}\text { This technique saved } \\
\text { approximately } 12 \mathrm{~h} \text { of } \\
\text { laboratory time, which is } \\
\text { normally spent on designing } \\
\text { surgical template. Eliminated } \\
\text { two clinical preoperative visits } \\
\text { of patient. The virtual planning } \\
\text { allowed the surgeon to plan the } \\
\text { incision and implant emergence } \\
\text { site according to } \\
\text { prosthetic boundaries. }\end{array}$ \\
\end{tabular}

Recommendations

While treating the unilateral defect, the implants location and prosthetic design are decided on the basis of mirrored image data from non-affected side. Therefore with all virtual planning, preoperative impression is not required.

\section{Following silicone}

vulcanization, the lower pieces of mold should be separated first, and ocular resin models should be carefully removed from prosthesis after they separate from upper pieces of mold. This sequence will prevent damage to silicone prosthesis. reduced the visits of patients.

The ocular defect was accurately restored. The structure of eyelid and the wrinkles were clear. The size, marginal adaptat The digital planning and designing saved the time and
Limitation of this specific technique was the inability to estimate the trajectory of registered drill in contra-angle hand-piece during implants osteotomy when utilizing this navigation platform. As the contra-angle hand-piece might be needed in anatomical location with limited space such as while orbital implants placement.

Bi, Y. et al., 2013 [35] The data set allowed fast and accurate sculpturing to refine Weisson, E.H. et al., 2020 [36] the prosthesis edge-skin interface without the need of patient physically present.

The implants were successfully and precisely placed according to digital planning. No complications were

Zhang, X. et al., 2007 [37] encountered. Surgical time had reduced as compared to conventional methods. Orbital prosthesis had fit over the implants and patients were satisfied from final outcome.
This technique reduces the cost and fabrication time of prosthesis in the case, if it is damaged or lost.
The 3D printer utilized in this study took $20 \mathrm{~h}$ to print the mold, which according to authors, can be reduced by industrial type $3 \mathrm{D}$ printers.
Improvement in software is needed, to enable mirroring of healthy eye on the defect side, which is important for orientation during planning.
The number of cases was too small for statistical analysis to check the accuracy of this system.
The stereolithographic surgical template served to transfer individualized plan to operating room for orbital implants placement. During surgery, templates fitted well on orbital rim. There was no need to shift the implant position from originally planned position. Surgery was more predictable and less dependent on surgical skills.
Magnetic retention was recommended as it offers adequate retention, ease of orbital prosthesis placement and better access for hygiene maintenance.
According to authors, long-term survival of implants in orbital defect area was unpredictable due to poor bone quality and radiation dose. 
Digital workflow for designing of surgical templates and manufacturing of Orbital prostheses.

CT/CBCT/MRI/MDCT

Surface scans

Computer aided designing (CAD)

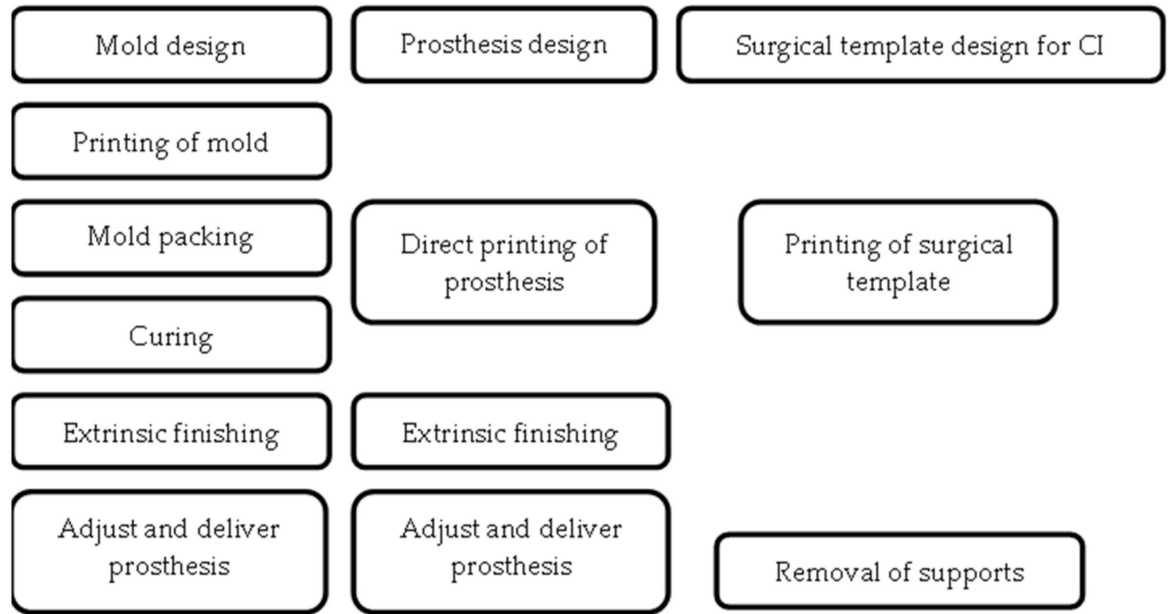

Figure 4. Digital workflow for the designing of surgical templates and manufacturing of orbital prostheses.

Table 6. Estimated time for the designing and manufacturing of orbital prosthesis through digital workflow.

\begin{tabular}{cccc}
\hline \multicolumn{2}{c}{ Weisson, E.H. et al., 2020 [36] } & \multicolumn{2}{c}{ Bi, Y. et al., 2013 [35] } \\
\hline Procedures & Estimated Time (hour) & Procedures & Estimated Time (hour) \\
\hline Facial topography mapping & $1 \mathrm{~h}$ & Data acquisition & \multirow{2}{*}{$5 \mathrm{~h}$} \\
\cline { 1 - 3 } Digital design and printing of mold & $26 \mathrm{~h}$ & Fabrication of prosthesis & \\
\hline Manufacturing of prosthesis & $17 \mathrm{~h}$ & Finishing and delivery & $13.5 \mathrm{~h}$ \\
\hline Finishing and delivery & $2 \mathrm{~h}$ & Digital design and fabrication & $18.5 \mathrm{~h}$ \\
\hline Total time & $46 \mathrm{~h}$ & Total time & \\
\hline
\end{tabular}

This systematic review gathered clinical case studies that presented a digital workflow from data acquisition to the designing and printing of models, substructures, molds, surgical templates and provisional prostheses. The available literature has demonstrated that CAD/CAM systems provide predictable outcomes, time- and cost-saving solutions and patient satisfaction. Clinical applications of CAD/CAM systems have shown promising results in this review in terms of orbital implant planning and placement, mold fabrication for silicone packing, the orientation of substructures to retain orbital prostheses, waxup for quick trial steps and the fabrication of provisional prostheses. Few nonclinical studies [56-58] have been conducted to assess the accuracy of CAD/CAM systems in orbital implants placement and the fabrication of orbital prostheses, with varying results (Table 7). However, there are no clinical trials to show the accuracy and precision of these CAD/CAM systems in clinical settings for orbital implants placement and the fabrication of orbital prostheses. Furthermore, the direct printing of silicone orbital prostheses is not yet evident from the literature, which might be due to the limitations of the orientation of ocular prostheses while using the direct printing of silicone. Therefore, future technical developments and clinical trials can be directed to answer these questions. 
Table 7. Nonclinical studies that assessed the accuracies of digital systems for orbital implants placement and the fabrication of orbital prosthesis.

\begin{tabular}{|c|c|c|c|c|c|c|c|}
\hline Publications & $\begin{array}{c}\text { Purpose of } \\
\text { Software Planning }\end{array}$ & $\begin{array}{l}\text { Pre-Op Data for } \\
\text { Digital Planning }\end{array}$ & Software & Printer/Miller & $\begin{array}{l}\text { Printing } \\
\text { Materials }\end{array}$ & Outcome & Limitations \\
\hline $\begin{array}{c}\text { Bockey, S. et al., } \\
2018 \text { [56] }\end{array}$ & $\begin{array}{l}\text { To Assess, if the } \\
\text { method of digital } \\
\text { designing of orbital } \\
\text { models for orbital } \\
\text { prostheses is } \\
\text { suitable for patients? } \\
\text { Comparison was } \\
\text { made among } \\
4 \text { groups; mirror eye, } \\
\text { CAD prosthesis, cut } \\
\text { out defect area and } \\
\text { manually } \\
\text { designed prosthesis }\end{array}$ & $\begin{array}{l}\text { 3D surface scans } \\
\text { of } 32 \text { patients } \\
\text { were captured } \\
\text { through fringe } \\
\text { projection } \\
\text { method. } \\
\text { Measuring } \\
\text { accuracy of high } \\
\text { resolution is } \\
0.3 \mathrm{~mm}\end{array}$ & $\begin{array}{l}\text { 3D software; } \\
\text { pVision3D, } \\
\text { Rhinoceros (Robert } \\
\text { McNeel \& Associates, } \\
\text { version } 4.0 \text { ) }\end{array}$ & $\begin{array}{l}\text { 3D printer (OBJET } \\
\text { EDEN 260V, Stratasys } \\
\text { Ltd., Eden Prairie, } \\
\text { USA). With accuracy } \\
\text { of } 600 \text { dpi lateral and } \\
1600 \text { dpi axial. }\end{array}$ & $\begin{array}{l}\text { VeroDent } \\
\text { MED-670 and } \\
\text { VeroDent Plus } \\
\text { MED-690. }\end{array}$ & $\begin{array}{l}\text { Mirrored eye had the lowest } \\
\text { asymmetry index (AI) while the } \\
\text { manually designed orbital } \\
\text { prosthesis had highest asymmetry } \\
\text { index. The deviation of mean } \\
\text { values between these groups was } \\
\text { 0.33. The results indicated that the } \\
\text { use of this technique can help to } \\
\text { increase the facial symmetry of } \\
\text { prosthesis and can further assist } \\
\text { Anaplastologists in technical } \\
\text { procedures, as the mirrored eye is } \\
\text { the direct template of prosthesis, } \\
\text { which could be adjusted manually. }\end{array}$ & $\begin{array}{l}\text { In this study, the } \\
\text { question of appropriate } \\
\text { implant location and } \\
\text { subsequent } \\
\text { reconstruction heights } \\
\text { were not included. It was } \\
\text { not possible to record the } \\
\text { position of abutments } \\
\text { due to undercuts. } \\
\text { Furthermore, this } \\
\text { method of reconstruction } \\
\text { is only suitable for } \\
\text { paired structures, such as } \\
\text { eyes, ears. }\end{array}$ \\
\hline $\begin{array}{l}\text { Marafon, P.G. } \\
\text { et al., } 2010 \text { [57] }\end{array}$ & $\begin{array}{l}\text { To determine the } \\
\text { dimensional } \\
\text { accuracy of orbital } \\
\text { prostheses } \\
\text { manufactured } \\
\text { through } \\
\text { CAD/CAM system } \\
\text { by utilizing CT scan. }\end{array}$ & CT scan & $\begin{array}{l}\text { InVesalius Software } \\
\text { (CTI-Information } \\
\text { Technology Center), } \\
\text { Magics Software } \\
\text { (Magics X SP2 v.1.1.17, } \\
\text { Materialise), } \\
\text { Rhinoceros Software v. } \\
4.0 \text { (Robert McNeel \& } \\
\text { Associates), } \\
\text { SolidWorks Software } \\
\text { v. 2008 } \\
\text { (Dassault Systèmes) }\end{array}$ & $\begin{array}{l}\text { Selective laser } \\
\text { sintering (SLA) } \\
\text { (Sinterstation 2000, } \\
\text { 3D Systems) }\end{array}$ & $\begin{array}{l}\text { Polyamide } \\
\text { (Robotec) }\end{array}$ & $\begin{array}{l}\text { There was no significant } \\
\text { difference between the position of } \\
\text { landmarks on the prosthesis and } \\
\text { the landmarks on the face, } \\
\text { indicating no significant } \\
\text { displacement of orbital prosthesis } \\
\text { in transverse or oblique directions. } \\
\text { Furthermore no significant } \\
\text { difference between the } \\
\text { measurements of the cast and on } \\
\text { the orbital prosthesis, thus } \\
\text { indicating that the dimensions of } \\
\text { orbital prosthesis were stable in } \\
\text { transverse, oblique and vertical } \\
\text { directions. The dimensional } \\
\text { accuracy of orbital prosthesis } \\
\text { suggested that CAD/CAM system } \\
\text { maybe suitable for clinical use. }\end{array}$ & - \\
\hline
\end{tabular}


Table 7. Cont.

\begin{tabular}{|c|c|c|c|c|c|c|c|}
\hline Publications & $\begin{array}{l}\text { Purpose of Software } \\
\text { Planning }\end{array}$ & $\begin{array}{l}\text { Pre-Op Data for } \\
\text { Digital Planning }\end{array}$ & Software & Printer/Miller & $\begin{array}{l}\text { Printing } \\
\text { Materials }\end{array}$ & Outcome & Limitations \\
\hline $\begin{array}{l}\text { Dings, J.P.J. } \\
\text { et al., } 2019 \text { [58] }\end{array}$ & $\begin{array}{l}\text { To determine the } \\
\text { accuracy of guided } \\
\text { implants placement } \\
\text { by using CAD/CAM } \\
\text { system to design skin } \\
\text { supported digital } \\
\text { surgical template }\end{array}$ & $\mathrm{CBCT}$ & $\begin{array}{l}\text { Maxilim software } \\
\text { (Medicim NV, } \\
\text { Mechelen, Belgium), } \\
\text { Procera System } \\
\text { (NobelGuide; Nobel } \\
\text { Biocare, Goteborg, } \\
\text { Sweden) }\end{array}$ & NM & $\begin{array}{l}\text { Biocompatible } \\
\text { resin }\end{array}$ & $\begin{array}{l}\text { One hundred and thirty-six } \\
\text { craniofacial Branemark MK III } \\
\text { implants were placed in } 10 \\
\text { cadaver heads. Out of total } \\
136 \text { implants, } 57 \text { implants were } \\
\text { placed in orbital region. The } \\
\text { use of fixation pins showed } \\
\text { higher mean deviation at } \\
\text { implants shoulder, angle and } \\
\text { depth when compared to } \\
\text { non-fixated surgical templates. } \\
\text { Surgical templates without } \\
\text { fixation pins showed } \\
\text { non-significant difference in } \\
\text { angular deviation. }\end{array}$ & $\begin{array}{l}\text { All cadaver heads } \\
\text { were edentulous } \\
\text { therefore there were } \\
\text { no ideal fixed } \\
\text { reference points to } \\
\text { design the hard } \\
\text { tissue supported } \\
\text { surgical templates. }\end{array}$ \\
\hline
\end{tabular}




\section{Conclusions}

CAD/CAM systems have been gaining popularity in pre-surgical and pre-prosthetic planning, designing and printing of implant surgical templates and maxillofacial prostheses. It can be stated that digital planning for the rehabilitation of orbital defects is the most reliable step of the digital workflow as it reduces patient visits, laboratory and clinical time and provides a predictable final outcome. However, the availability of skilled technical staff and equipment costs are still limiting access to digital systems. The direct printing of definitive orbital prostheses is limited by the difficulty in ocular prosthesis orientation within silicone orbital prostheses, the color matching of printed silicone with adjacent skin tones and the marginal thickness. Therefore, further technical advancements are needed to overcome the above-mentioned limitations, while human clinical trials would help to determine the accuracy and precision of these digital systems for craniofacial implant placement and the fabrication of orbital prostheses.

Author Contributions: Conceptualization, W.T., A.R.-P. and T.F.; methodology, W.T., A.R.-P. and T.F.; validation, W.T., A.R.-P. and T.F.; formal analysis, W.T. and P.M.-M.; resources, W.T. and P.M.-M.; writing - original draft preparation, W.T.; writing—review and editing, W.T. and supervision, A.R.-P. and T.F. All authors have read and agreed to the published version of the manuscript.

Funding: This research received no external funding.

Institutional Review Board Statement: Ethical review and approval were waived for this study, due to the retrospective data, which was readily available through published papers. Therefore, no direct human or animal contact was involved for gathering this data.

Informed Consent Statement: Not applicable for this systematic review.

Data Availability Statement: Not applicable for this systematic review.

Conflicts of Interest: The authors declared no conflict of interest.

\section{References}

1. Dings, J.P.J.; Merkx, M.A.W.; de Clonie Maclennan-Naphausen, M.T.P.; van de Pol, P.; Maal, T.J.J.; Meijer, G.J. Maxillofacial prosthetic rehabilitation: A survey on the quality of life. J. Prosthet. Dent. 2018, 120, 780-786. [CrossRef]

2. Atay, A.; Peker, K.; Günay, Y.; Ebrinç, S.; Karayazgan, B.; Uysal, Ö. Assessment of health-related quality of life in Turkish patients with facial prostheses. Health Qual. Life Outcomes 2013, 11, 11. [CrossRef]

3. De Oliveira, F.M.; Salazar-Gamarra, R.; Öhman, D.; Nannmark, U.; Pecorari, V.; Dib, L.L. Quality of life assessment of patients utilizing orbital implant-supported prostheses. Clin. Implant Dent. Relat. Res. 2018, 20, 438-443. [CrossRef]

4. Nemli, S.K.; Aydin, C.; Yilmaz, H.; Bal, B.T.; Arici, Y.K. Quality of life of patients with implant-retained maxillofacial prostheses: A prospective and retrospective study. J. Prosthet. Dent. 2013, 109, 44-52. [CrossRef]

5. Gastaldi, G.; Palumbo, L.; Moreschi, C.; Gherlone, E.F.; Capparé, P. Prosthetic management of patients with oro-maxillo-facial defects: A long-term follow-up retrospective study. J. Oral Implantol. 2017, 10, 276-282. [CrossRef]

6. Smolarz-Wojnowska, A.; Raithel, F.; Gellrich, N.C.; Klein, C. Quality of implant anchored craniofacial and intraoral prostheses: Patient's evaluation. J. Craniofac. Surg. 2014, 25, e202-e207. [CrossRef] [PubMed]

7. Miles, B.A.; Sinn, D.P.; Gion, G.G. Experience with cranial implant-based prosthetic reconstruction. J. Craniofac. Surg. 2006, 17, 889-897. [CrossRef] [PubMed]

8. Visser, A.; Raghoebar, G.M.; van Oort, R.P.; Vissink, A. Fate of implant-retained craniofacial prostheses: Life span and aftercare. Int. J. Oral Maxillofac. Implants 2008, 23, 89-98.

9. Abu-Serriah, M.M.; McGowan, D.A.; Moos, K.F.; Bagg, J. Outcome of extra-oral craniofacial endosseous implants. Br. J. Oral Maxillofac. Surg. 2001, 39, 269-275. [CrossRef]

10. Jacobsson, M.; Tjellstrom, A.; Fine, L.; Andersson, H. A retrospective study of osseointegrated skin-penetrating titanium fixtures used for retaining facial prostheses. Int. J. Oral Maxillofac. Implants 1992, 7, 523-528.

11. Nishimura, R.D.; Roumanas, E.; Moy, P.K.; Sugai, T.; Freymiller, E.G. Osseointegrated implants and orbital defects: U.C.L.A. experience. J. Prosthet. Dent. 1998, 79, 304-309. [CrossRef]

12. Toljanic, J.A.; Eckert, S.E.; Roumanas, E.; Beumer, J.; Huryn, J.M.; Zlotolow, I.M.; Reisberg, D.J.; Habakuk, S.W.; Wright, R.F.; Rubenstein, J.E.; et al. Osseointegrated craniofacial implants in the rehabilitation of orbital defects: An update of a retrospective experience in the United States. J. Prosthet. Dent. 2005, 94, 177-182. [CrossRef] [PubMed]

13. Roumanas, E.D.; Freymiller, E.G.; Chang, T.L.; Aghaloo, T.; Beumer, J., 3rd. Implant-retained prostheses for facial defects: An up to 14-year follow-up report on the survival rates of implants at UCLA. Int. J. Prosthodont. 2002, 15, 325-332. [PubMed] 
14. Zhang, X.; Chen, S.L.; Zhang, J.M.; Chen, J.L. Fabrication of a surgical template for orbital implant placement: A case report. Int. J. Oral Maxillofac. Implants 2010, 25, 826-830.

15. Buser, D.; Sennerby, L.; De Bruyn, H. Modern implant dentistry based on osseointegration: 50 years of progress, current trends and open questions. Periodontology 2000, 73, 7-21. [CrossRef]

16. Tahmaseb, A.; Wismeijer, D.; Coucke, W.; Derksen, W. Computer technology applications in surgical implant dentistry: A systematic review. Int. J. Oral Maxillofac. Implants 2014, 29, 25-42. [CrossRef]

17. Sarment, D.P.; Sukovic, P.; Clinthorne, N. Accuracy of implant placement with a stereolithographic surgical guide. Int. J. Oral Maxillofac. Implants 2003, 18, 571-577.

18. Tanveer, W.; Ridwan-Pramana, A.; Molinero-Mourelle, P.; Koolstra, J.H.; Forouzanfar, T. Systematic Review of Clinical Applications of CAD/CAM Technology for Craniofacial Implants Placement and Manufacturing of Nasal Prostheses. Int. J. Environ. Res. Public Health 2021, 18, 3756. [CrossRef]

19. Verma, S.N.; Schow, S.R.; Stone, B.H.; Triplett, R.G. Applications of surgical navigational systems for craniofacial bone-anchored implant placement. Int. J. Oral Maxillofac. Implants 2010, 25, 582-588. [PubMed]

20. Block, M.S.; Emery, R.W.; Cullum, D.R.; Sheikh, A. Implant Placement Is More Accurate Using Dynamic Navigation. J. Oral Maxillofac. Surg. 2017, 75, 1377-1386. [CrossRef]

21. D'Haese, J.; Ackhurst, J.; Wismeijer, D.; De Bruyn, H.; Tahmaseb, A. Current state of the art of computer-guided implant surgery. Periodontology 2000, 73, 121-133. [CrossRef] [PubMed]

22. Moher, D.; Liberati, A.; Tetzlaff, J.; Altman, D.G. Preferred reporting items for systematic reviews and meta-analyses: The PRISMA statement. PLoS Med. 2009, 6, e1000097. [CrossRef] [PubMed]

23. Moola, S.; Aromataris, E.; Sears, K.; Sfetcu, R.; Currie, M.; Lisy, K.; Qureshi, R.; Mattis, P.; Mu, P. Chapter 7: Systematic reviews of etiology and risk. In Joanna Briggs Institute Reviewer's Manual; Aromataris, E., Munn, Z., Eds.; JBI: Adelaide, Australia, 2017. [CrossRef]

24. Li, S.; Xiao, C.; Duan, L.; Fang, C.; Huang, Y.; Wang, L. CT image-based computer-aided system for orbital prosthesis rehabilitation. Med. Biol. Eng. Comput. 2015, 53, 943-950. [CrossRef] [PubMed]

25. Ciocca, L.; Scotti, R. Oculo-facial rehabilitation after facial cancer removal: Updated CAD/CAM procedures: A pilot study. Prosthet. Orthot. Int. 2014, 38, 505-509. [CrossRef]

26. Liu, H.; Bai, S.; Yu, X.; Zhao, Y. Combined use of a facial scanner and an intraoral scanner to acquire a digital scan for the fabrication of an orbital prosthesis. J. Prosthet. Dent. 2019, 121, 531-534. [CrossRef]

27. Yoshioka, F.; Ozawa, S.; Okazaki, S.; Tanaka, Y. Fabrication of an orbital prosthesis using a noncontact three-dimensional digitizer and rapid-prototyping system. J. Prosthodont. 2010, 19, 598-600. [CrossRef]

28. Sabol, J.V.; Grant, G.T.; Liacouras, P.; Rouse, S. Digital image capture and rapid prototyping of the maxillofacial defect. J. Prosthodont. 2011, 20, 310-314. [CrossRef] [PubMed]

29. Eo, M.Y.; Cho, Y.J.; Nguyen, T.T.H.; Seo, M.H.; Kim, S.M. Implant-supported orbital prosthesis: A technical innovation of silicone fabrication. Int. J. Implant Dent. 2020, 6, 51. [CrossRef]

30. Huang, Y.H.; Seelaus, R.; Zhao, L.; Patel, P.K.; Cohen, M. Virtual surgical planning and 3D printing in prosthetic orbital reconstruction with percutaneous implants: A technical case report. Int. Med. Case Rep. J. 2016, 9, 341-345. [CrossRef]

31. Chiu, M.; Hong, S.C.; Wilson, G. Digital fabrication of orbital prosthesis mold using 3D photography and computer-aided design. Graefe's Arch. Clin. Exp. Ophthalmol. 2017, 255, 425-426. [CrossRef]

32. Choi, K.J.; Sajisevi, M.B.; McClennen, J.; Kaylie, D.M. Image-Guided Placement of Osseointegrated Implants for Challenging Auricular, Orbital, and Rhinectomy Defects. Ann. Otol. Rhinol. Laryngol. 2016, 125, 801-807. [CrossRef]

33. Ciocca, L.; Fantini, M.; Marchetti, C.; Scotti, R.; Monaco, C. Immediate facial rehabilitation in cancer patients using CAD-CAM and rapid prototyping technology: A pilot study. Support Care Cancer 2010, 18, 723-728. [CrossRef] [PubMed]

34. Verma, S.; Gonzalez, M.; Schow, S.R.; Triplett, R.G. Virtual Preoperative Planning and Intraoperative Navigation in Facial Prosthetic Reconstruction: A Technical Note. Int. J. Oral Maxillofac. Implants 2017, 32, e77-e81. [CrossRef]

35. Bi, Y.; Wu, S.; Zhao, Y.; Bai, S. A new method for fabricating orbital prosthesis with a CAD/CAM negative mold. J. Prosthet. Dent. 2013, 110, 424-428. [CrossRef]

36. Weisson, E.H.; Fittipaldi, M.; Concepcion, C.A.; Pelaez, D.; Grace, L.; Tse, D.T. Automated Noncontact Facial Topography Mapping, 3-Dimensional Printing, and Silicone Casting of Orbital Prosthesis. Am. J. Ophthalmol. 2020, 220, 27-36. [CrossRef] [PubMed]

37. Zhang, X.; Chen, S.; Huang, Y.; Chang, S. Computer-assisted design of orbital implants. Int. J. Oral Maxillofac. Implants 2007, 22, 132-137.

38. Goh, B.T.; Teoh, K.H. Orbital implant placement using a computer-aided design and manufacturing (CAD/CAM) stereolithographic surgical template protocol. Int. J. Oral Maxillofac. Surg. 2015, 44, 642-648. [CrossRef] [PubMed]

39. Ewers, R.; Schicho, K.; Truppe, M.; Seemann, R.; Reichwein, A.; Figl, M.; Wagner, A. Computer-aided navigation in dental implantology: 7 years of clinical experience. J. Oral Maxillofac. Surg. 2004, 62, 329-334. [CrossRef] [PubMed]

40. Mupparapu, M.; Singer, S.R. Implant imaging for the dentist. J. Can. Dent. Assoc. 2004, 70, 32. [PubMed]

41. Jacobs, R.; Adriansens, A.; Verstreken, K.; Suetens, P.; van Steenberghe, D. Predictability of a three-dimensional planning system for oral implant surgery. Dento Maxillo Fac. Radiol. 1999, 28, 105-111. [CrossRef] 
42. Israelson, H.; Plemons, J.M.; Watkins, P.; Sory, C. Barium-coated surgical stents and computer-assisted tomography in the preoperative assessment of dental implant patients. Int. J. Periodont. Restor. Dent. 1992, 12, 52-61.

43. Basten, C.H. The use of radiopaque templates for predictable implant placement. Quintessence Int. 1995, 26, 609-612.

44. Mizrahi, B.; Thunthy, K.H.; Finger, I. Radiographic/surgical template incorporating metal telescopic tubes for accurate implant placement. Pract. Periodont. Aesthet. Dent. 1998, 10, 757-765.

45. Verstreken, K.; Van Cleynenbreugel, J.; Martens, K.; Marchal, G.; van Steenberghe, D.; Suetens, P. An image-guided planning system for endosseous oral implants. IEEE Trans. Med. Imaging 1998, 17, 842-852. [CrossRef] [PubMed]

46. Choi, J.-Y.; Choi, J.-H.; Kim, N.-K.; Kim, Y.; Lee, J.-K.; Kim, M.-K.; Lee, J.-H.; Kim, M.-J. Analysis of errors in medical rapid prototyping models. Int. J. Oral Maxillofac. Surg. 2002, 31, 23-32. [CrossRef] [PubMed]

47. Whyms, B.J.; Vorperian, H.K.; Gentry, L.R.; Schimek, E.M.; Bersu, E.T.; Chung, M.K. The effect of computed tomographic scanner parameters and 3-dimensional volume rendering techniques on the accuracy of linear, angular, and volumetric measurements of the mandible. Oral Surg. Oral Med. Oral Pathol Oral Radiol. 2013, 115, 682-691. [CrossRef]

48. Taft, R.M.; Kondor, S.; Grant, G.T. Accuracy of rapid prototype models for head and neck reconstruction. J. Prosthet. Dent. 2011, 106, 399-408. [CrossRef]

49. D’Haese, J.; Van De Velde, T.; Komiyama, A.; Hultin, M.; De Bruyn, H. Accuracy and complications using computer-designed stereolithographic surgical guides for oral rehabilitation by means of dental implants: A review of the literature. Clin. Implant Dent. Relat. Res. 2012, 14, 321-335. [CrossRef]

50. Alauddin, M.S.; Baharuddin, A.S.; Mohd Ghazali, M.I. The Modern and Digital Transformation of Oral Health Care: A Mini Review. Healthcare 2021, 9, 118. [CrossRef] [PubMed]

51. Ishida, Y.; Miura, D.; Miyasaka, T.; Shinya, A. Dimensional Accuracy of Dental Casting Patterns Fabricated Using Consumer 3D Printers. Polymers 2020, 12, 2244. [CrossRef] [PubMed]

52. Dawood, A.; Marti, B.; Sauret-Jackson, V.; Darwood, A. 3D printing in dentistry. Br. Dent. J. 2015, 219, 521-529. [CrossRef] [PubMed]

53. Stansbury, J.W.; Idacavage, M.J. 3D printing with polymers: Challenges among expanding options and opportunities. Dental materials. Dent. Mater. 2016, 32, 54-64. [CrossRef] [PubMed]

54. Nayar, S.; Bhuminathan, S.; Bhat, W.M. Rapid prototyping and stereolithography in dentistry. J. Pharm. Bioallied Sci. 2015, 7, 16-19. [CrossRef]

55. Khorsandi, D.; Fahimipour, A.; Saber, S.S.; Ahmad, A.; De Stephanis, A.A. Fused Deposition Modeling and Stereolithography 3D Bioprinting in Dental Science. EC Dent. Sci. 2019, 18, 110-115. [CrossRef]

56. Bockey, S.; Berssenbrügge, P.; Dirksen, D.; Wermker, K.; Klein, M.; Runte, C. Computer-aided design of facial prostheses by means of 3D-data acquisition and following symmetry analysis. J. Cranio-Maxillo-Fac. Surg. 2018, 46, 1320-1328. [CrossRef] [PubMed]

57. Marafon, P.G.; Mattos, B.S.; Sabóia, A.C.; Noritomi, P.Y. Dimensional accuracy of computer-aided design/computer-assisted manufactured orbital prostheses. Int. J. Prosthodont. 2010, 23, 271-276. [PubMed]

58. Dings, J.P.J.; Verhamme, L.; Maal, T.J.J.; Merkx, M.A.W.; Meijer, G.J. Reliability and accuracy of skin-supported surgical templates for computer-planned craniofacial implant placement, a comparison between surgical templates: With and without bony fixation. J. Cranio-Maxillo-Fac. Surg. 2019, 47, 977-983. [CrossRef] 